\title{
DESCORTINANDO O BRINCAR A OFICINA TEATRAL COMO EXPERIÊNCIA NA EMEF TOMÁZ DE AQUINO DE OLIVEIRA NETO EM SÃO MIGUEL DO GUAMÁ- PA
}

Resumo: O presente artigo parte de um processo de experiência com a linguagem teatral desenvolvida a partir dos jogos teatrais, tendo como sujeito as professoras que desenvolvem sua praxe pedagógica na escola municipal de ensino fundamental Tomaz de Aquino de Oliveira Neto localizada no município de São Miguel do Guamá-Pa. Para tanto, a proposta de oficina teatral em um período de uma semana no mês de fevereiro no ano de 2017, nas dependências da escola foram os elementos que encadearam os encontros matinais com o coletivo de 12 professoras com faixa etária de 38 a 42 anos pertencente ao quadro efetivo de servidores municipais. Logo, com o ato de se permitir no jogo construindo uma maneira peculiar de conhecimento e ações foram se envolvendo com os jogos teatrais descobrindo a atividade do jogar como um viés de possibilidades de descontração, espontaneidade e alegria exalando um clima favorável com comportamentos brincantes que integralizou as professoras e, ao mesmo tempo evocou reminiscências brincadas no coletivo e em mim enquanto pesquisadora e jogadora no grupo de professoras.

Neste sentido, a descrição desse relevante momento passou a se concretizar a partir do dia vinte e sete de janeiro de 2017, quando procurei a gestão da escola para compartilhar a intenção em fazer acontecer a oficina de teatro pautada na investigação para o curso de mestrado norteada pelos teóricos FREIRE (1996), MERLEAU-PONTY (1999), BOAL (2009), PARKER J. (2012), KOUDELLA (2011) e SPOLIN (2008) entre outros que referendam o processo pelo meandro tomado. Para tanto, informamos que a pesquisa de cunho aplicada busca de forma prática a solução dos problemas identificados aliado aos caminhos procedimentais que faz-se relevante comentar numa abordagem qualitativa em que a observação participante foi o registro fotográfico em ação ao buscar capturar não apenas imagens, mas um conjunto de elementos que pudesse teorizar a experiência de caráter fenomenológico vivida entre e com os sujeitos. Assumindo dessa forma, do ponto de vista técnico uma metodologia de pesquisa ação ao oportunizar o ensejo ao corpo docente um exercício de experiência através de jogos teatrais.

E na nuança das possibilidades fomos despertando nosso corpo adulto a redescobrir a leveza do experimento deixando fluir o brincar, que necessitava da convivência do outro, da integração em grupo e da atuação consciente de que tudo se tratava de um jogo. E que ciente dos fatos, não nos impedimos de exercer com entusiasmo a alegria de recomeçar a brincar 
deixando o devir criança atuar na ação da cena com comportamentos, vozes alteradas e gargalhadas constantes que causava certo desconforto mediante as situações que vivíamos estando em um contato diferencial do cotidiano.

Portanto, o caminho traçado com os jogos teatrais viabilizou a busca do coletivo para atuarmos de forma sistematizada, trazendo lembranças e sentimentos que reativaram o baú da memória pelo valor construído e consolidado na relação advinda com os jogos transformando nosso estado de humor em emoções que nos proporcionaram prazer brincando. Assim, cantando, criando movimento para o corpo, anotando no pequeno caderno o ocorrido em sala, relacionando prática pedagógica com pratica teatral, saindo e retornando da sala ou simplesmente se distraído com as bexigas fixada na parede nos conduziu construir acordos técnicos/práticos que impulsionaram nossos corpos e mentes a nos conhecer de maneira espontânea, livre, alegre e muito divertida na descoberta da experiência brincada que o jogo teatral assumiu no coletivo de professoras.

PALAVRAS-CHAVE: Jogos Teatrais. Oficina de Teatro. Experiência. Transformação. Professoras.

\section{REFERENCIAS}

BOAL, Augusto, 1931- 2009. A Estética do Oprimido. Rio de Janeiro : Garamond, 2009.

FREIRE, Paulo. Educação e Mudança. Tradução de Moacir Gadotti e Lilian Lopes Martin. Rio de Janeiro: Paz e Terra, 1983 (Coleção Educação e Mudança vol. 1).

KOUDELA, Ingrid Dormien. Jogos teatrais. - São Paulo: Perspectiva, 2011. - (debates; 189 / dirigida por J. Guinsburg).

MERLEAU-PONTY, Maurice, 1908 - 1961. Fenomenologia da Percepção. [Tradução Carlos Alberto Ribeiro de Moura]. - 2 - ed. - São Paulo: Martins Fontes, 1999. (Tópicos).

SPOLIN, Viola, 1906 - 1994. Jogos Teatrais para a sala de aula: um manual para o professor / Viola Spolin; [tradução Ingrid Dormien Koudela] - São Paulo: Perspectiva, 2008. 